\title{
Comparing Mainland Chinese Tourists' Satisfaction with Hong Kong and the UK Using Tourist Satisfaction Index ${ }^{1}$ 基于旅客满意指数比较中国大陆旅客 对香港和英国的满意度
}

\author{
GANG LI \\ HAIYAN SONG \\ JASON LI CHEN \\ DORIS CHENGUANG WU
}

This study aims to assess mainland Chinese tourists' satisfaction with the UK and Hong Kong using a Tourist Satisfaction Index (TSI) approach. Based on a survey with mainland Chinese tourists in the UK who also visited Hong Kong recently, this study computes the overall destination TSIs and sectoral TSIs for both Hong Kong and the $U K$. The results suggest that overall mainland Chinese tourists were more satisfied with Hong Kong than with the UK as their travel destinations. With respect to individual service sectors, mainland Chinese tourists were more satisfied with six out of the seven surveyed tourism-related service sectors in Hong Kong than their counterparts in the UK. Visitor attractions, hotels and local tour operators show the most significant contribution to mainland Chinese tourists' overall satisfaction evaluation with both destinations. These findings suggest that Hong Kong's tourism industry as whole is more competitive than that of the UK as far as mainland Chinese tourists are concerned. Cross-cultural perspectives should be adopted in tourism service operations at an international tourist destination.

KEYWORDS. Tourist satisfaction index, Chinese tourists, structural equation modelling, Hong Kong, UK

本研究采用旅客满意指数 (TSI) 方法, 旨在评估中国大陆旅客对英国和香港的满 意度。基于对最近曾到访香港、现正身处英国的中国大陆旅客的调查, 本研究 对香港和英国两地的整体目的地满意指数和不同行业的满意指数进行了计算和 评估。结果显示, 中国大陆旅客对香港作为旅游目的地的满意度整体高于英 国。

从七个旅游相关服务行业的比较结果来看, 在其中六个行业中, 中国大陆旅 客对香港的满意度均高于英国。旅游景点、酒店及当地旅行社是影响中国旅客 对香港和英国两地的整体满意评价的三个主要因素。本文研究结果指出, 就中 国大陆旅客而言, 香港旅游业整体上较英国更具竞争力。在国际旅游目的地的 旅游服务运营方面应采用跨文化观点。

关键词：旅客满意指数，中国旅客，结构方程模型，香港，英国

\footnotetext{
${ }^{1}$ To cite the paper:

Li G, Song H, Chen JL, Wu DC. (2012). Comparing mainland Chinese tourists' satisfaction with Hong Kong and the UK using tourist satisfaction index. Journal of China Tourism Research, 8, pp. 371-392. doi: 10.1080/19388160.2012.729402
} 


\section{Introduction}

The rapid economic development of China has led to a dramatic increase in personal disposable income, an improved living standard, and a burgeoning Chinese middle class with enormous spending power and the desire to travel abroad. The number of mainland Chinese outbound tourists increased from 3.74 million in 1993 to 57.4 million in 2010, representing an annual growth of $17.4 \%$ on average (United Nations World Tourism Organization [UNWTO], 2003; Zhang, Song, \& Liu, 2011). Despite the global economic downturn, the number of outbound trips by Chinese tourists still increased by $21 \%$ in 2010 (Zhang et al., 2011). Meanwhile, their expenditure during outbound travel increased by $17 \%$ in the same year against the previous one (Zhang et al., 2011). A substantial increase in mainland Chinese outbound tourists is stated in the World Tourism Organization Tourism Vision 2020 report, which forecasts 100 million mainland Chinese outbound tourists by 2020 (UNWTO, 1999). This number will account for $6.2 \%$ of the world's outbound tourist market and ranks fourth among outbound tourist generating countries, following German, Japanese and US tourists (UNWTO, 1999).

The significant contribution of Chinese outbound tourism to the world tourism development has been recognised by many tourist destinations, and strategic plans have been developed to target and compete for this emerging market. Therefore, it is important for the tourism industry in these destinations to understand the behaviour of this market and provide satisfactory services to meet their needs and wants in order to gain and maintain competitiveness. Although increasing attention has been paid to this rising market, more in-depth, vigorous marketing research is still needed (Chon, 2005; Wang \& Davidson, 2010). The present study aims to bring a new addition to the literature.

Tourist satisfaction has become an increasingly important issue for many destinations and tourism sectors that rely primarily on inbound tourists such as Hong Kong. Satisfied tourists are more likely to recommend the destination to their friends and relatives. This is the most effective way to promote a tourist destination. In addition, tourist satisfaction could contribute to the increased rates of retention of tourists' patronage, loyalty and acquisition (Li \& Carr, 2004), which will have important impact on the destination's economic growth in general.

The current study extends the research on Chinese outbound tourists' behaviour with particular attention paid to Chinese tourists' satisfaction with their various tourism experiences in a comparative setting. Two popular destinations for Chinese outbound travel are selected for the comparison in this study: Hong Kong and the UK. Hong Kong is the top destination of Chinese outbound tourism, and received 22.7 million Chinese visitors in 2010, which accounts for $40 \%$ of total outbound visits from China. This number also represents $63 \%$ of total inbound visitor arrivals that Hong Kong received in 2010 (Hong Kong Tourism Board, 2011; Zhang et al., 2011). Therefore, the importance of the mainland Chinese market for the Hong Kong tourism industry is well understood. Britain is a fast-growing long-haul destination for Chinese outbound tourism. In addition to the geographical distance, there is a great cultural distance between China and the UK, which becomes a key pull factor to attract Chinese tourists to visit the UK. It received 109 thousand visits from China and attracted 184 million pound tourism spending from this market in 2010 (VisitBritain, 2012). Although the UK's market share of Chinese 
outbound tourism is still low, its growth has been significant. The number of Chinese tourist arrivals and their spending increased by $15 \%$ and $40 \%$ respectively between 2005 and 2010 (VisitBritain, 2012). According to VisitBritain's forecasts, visits from China to the UK are expected to grow at a faster rate $(89 \%)$ than from any other source market by 2014, bringing just under an extra 100,000 tourists to the country (VisitBritain, 2010a). According to VisitBritain's research, increasing the UK's share of the Chinese outbound tourism market by half a per cent would generate an additional 2.5 billion pounds for the economy and create 50,000 new jobs (VisitBritain, 2010b). Given the great economic contribution of this market to the UK economy, especially under the current economic climate, it is important to understand the behavioural characteristics of this market and to enhance their satisfaction with the travel experience in the UK.

This study aims to evaluate mainland Chinese tourists' satisfaction with Hong Kong in comparison to their satisfaction with the UK. The contrasts between the two selected destinations allow an in-depth analysis leading to an enhanced understanding of Chinese tourists' behavioural characteristics. This is an extension of the studies by Song, Li, van der Veen, and Chen (2011) and Song, van der Veen, Li, and Chen (2012), who developed a Tourist Satisfaction Index (TSI) framework. This comparative study aims to achieve the following objectives:

1. To evaluate mainland Chinese tourists' satisfaction with key tourism-related service sectors in Hong Kong and in the UK, respectively;

2. To assess mainland Chinese tourists' overall satisfaction with Hong Kong and with the UK, respectively, based on the developed TSI conceptual model;

3. To investigate the relationships between sectoral satisfaction and overall satisfaction in Hong Kong and in the UK, respectively;

4. To compute the sectoral and overall tourist satisfaction indexes for Hong Kong and the UK, respectively;

5. To compare mainland Chinese tourists' satisfaction with Hong Kong and with the UK based on the computed satisfaction indexes.

By achieving the above objectives, the applicability of the developed TSI framework will be further verified. Moreover, new empirical evidence will be provided with regard to destination competitiveness in relation to Chinese outbound tourism. Useful implications can be drawn for the related tourism businesses and destination management organisations in these destinations.

\section{Literature Review}

Consumer satisfaction (CS) has always been one of the most important issues addressed by marketers, because a good understanding of CS is imperative for a firm to establish a long-term relationship with customers and to maintain long-term competitiveness (Henning-Thurau \& Klee, 1997). CS has been exhaustively researched over the last few decades. Although various approaches to the measurement of CS have been developed, a consensus has not yet been reached. Among various CS theories three satisfaction models attract the most attention in the literature: the expectation-perception paradigm (Parasuraman, Zeithaml, \& Berry, 1985), the performance-only model (Grönroos, 1984) and the expectancy-disconfirmation model (Oliver, 1980). The expectation-perception paradigm considers CS to be a reflection of either positive or negative gaps between the 
initial consumer expectations and perceptions of a product's performance, while the performance-only model regards CS as "an outcome of the actual quality of performance and its perception by consumers" (Kozak \& Rimmington, 2000, p. 261). The shortcoming of the performance-only model is that "it is impossible to interpret high levels of customer satisfaction as the results of low expectations or superior quality of service provider" (Fuchs \& Weiermair, 2004, p. 215). The expectation-perception approach is also criticised because consumers' expectations may be updated once they receive further information about the goods or services (Boulding, Kalra, Staeling, \& Zeithaml, 1993; Kozak \& Rimmington, 1999). The expectancy-disconfirmation model is further developed based on the expectation-perception concept. According to the theory, a customer has established certain expectations of the performance of the goods or services before purchasing them, and he or she tends to make comparison between the actual performance of the goods or services and his/her anticipation after consumption. Disconfirmation thus arises from the comparison. If the actual performance of the goods/services surpasses the expectation, positive disconfirmation is reached, which would then lead to the consumer's satisfaction and willingness to re-purchase. If the actual performance fails to meet the initial expectation, negative disconfirmation arrives. Within the expectancy-disconfirmation framework, a number of other models have been applied to CS studies, such as the congruity model (Sirgy, 1984). It suggests that CS depends on the comparison of the perceived performance of the goods or services concerned relative to the hypothetical ideal performance a consumer can imagine. The more congruent between the perceived and ideal performance, the more satisfied a consumer is likely to be. Other CS theories that have been developed include equity, attribution, comparison level, generalized negativity, value-precept, and so on (Oh \& Parks, 1997).

In the tourism literature, most of the above approaches have been applied to examine tourist satisfaction (TS) in various empirical contexts. Some studies focus on the overall levels of TS with a destination (e.g., Kau \& Lim, 2005), while others pay attention to specific attributes at the service encounter level such as a hotel, restaurant, travel agent, attraction, transport and retail shop (e.g., Heung, 2000; Wang, Vela, \& Tyler, 2008). The expectation-disconfirmation paradigm has become the most commonly applied theoretical foundation in TS research, given its broadly applicable conceptualisation. In addition to the importance for tourism service providers, the direct relevance of TS to destination competitiveness is well noted (Wong \& Law, 2003).

With regard to the measurement of TS, most studies use traditional single-item scales to obtain tourists' responses from "very dissatisfied" to "very satisfied". The drawbacks of this approach have been noted in the general CS literature, such as failure to capture the complexity of satisfaction evaluation, and higher possibility of measurement errors in a survey (Chan, Hui, Lo, Tse, Tso, \& Wu, 2003; Yi, 1990). As a result, the reliability of the findings is challenged (Yi, 1990). More recent satisfaction research regards satisfaction as a theoretical construct or latent variable, which cannot be measured directly (Fornell, 1992). Therefore, multi-item scales are more desirable to measure satisfaction. Oliver (1980) showed that the multi-item scales are significantly more reliable than single-item scales in an empirical study. In the tourism literature, most TS studies still employ single-item scales to measure the overall satisfaction, with few exceptions such as Yoon and Uysal (2005). In this study, four indicators are developed (and three are finally used) based on the expectancy-disconfirmation model, the 
performance-only model, the equality theory, and the norm theory, respectively. Future TS studies should consider such multi-item measurement.

Although tourist satisfaction has been extensively studied in the past few decades, only a few explored the issue in the context of Chinese outbound tourism. Focusing on Australia as a destination of Chinese outbound travel, Li and Carr (2004) found that Chinese tourists are more satisfied with natural attractions, clean and safe environment, but less satisfied with shopping, food and prices in Australia. For another destination, New Zealand, Ryan and Mo (2001) found that Chinese tourists are also satisfied with cultural attractions at the destination. Based on the SERVQUAR framework, Wang et al. (2008) found that Chinese tourists are dissatisfied with all 33 hotel attributes including restaurant services in the hotels in the UK. Communication barriers and different food cultures are identified as key issues. Kau and Lim (2005) examined the level of satisfaction of Chinese tourists to Singapore and segmented the sample according to tourists' travel motivations. They found that the overall satisfaction level of family/relaxation seekers is significantly higher than that of prestige/knowledge seekers, adventure/pleasure seekers and novelty seekers, with the last group being least satisfied. A few studies have focused on Chinese tourists' satisfaction with tourism services and facilities in Hong Kong. For instance, Qu and $\mathrm{Li}$ (1997) found that Chinese tourists are satisfied with infrastructure and facilities, environment and tourism services, but dissatisfied with prices for shopping and accommodation in Hong Kong. Using the disconfirmation model, Heung (2000) found that Chinese tourists are dissatisfied with 20 out of 34 attributes of Hong Kong hotels. It seems that Chinese tourists are generally less satisfied with accommodation than other services when they travel abroad. All of these studies focus on a single international destination that Chinese tourists visited. So far no comparative study has been found regarding Chinese tourists' satisfaction with different destinations. Thus the potential difference of Chinese tourists' travel behaviours and experiences at different destinations, especially those with great cultural distance, has not been well understood. In addition, the comparison of destination competitiveness as far as the Chinese tourist market would not be possible without such a comparative setting. The present study aims to bridge these gaps in the literature.

The interest in CS assessment has driven scholars and practitioners to further develop consumer satisfaction indexes (CSIs) to monitor the changes of households' satisfaction with the goods and services they purchase over time. However, no attempt had been made in comprehensively and continuously assessing CS in the tourism context until the development of the Hong Kong TSI (Song et al., 2011, 2012). The Hong Kong TSI framework is based on the previously developed CSIs especially the Hong Kong CSI model (Chan et al., 2003), but has its own unique features. First of all, the Hong Kong TSI is a two-stage tourist satisfaction evaluation system starting with the sectoral level assessment, which is then aggregated to the overall destination level. Secondly, the aggregation of the sectoral TSIs for computing the overall TSI is based on an innovative weighting scheme that is determined by the tourists' own evaluations. As a result, free-ofcharge and other public services can be included in TSI compilation. Thirdly, TSIs at both the sectoral and destination levels can be estimated and their relationships can be examined directly, thereby more useful policy implications can be derived for effective destination management. Figure 1 shows the conceptual model of tourist satisfaction assessment, in which tourist characteristics, expectation, perceived performance, assessed value are antecedents of tourist satisfaction, and tourist complaints and loyalty 
are consequences of tourist satisfaction. Each sectoral TSI is computed based on this model. All sectoral TSIs are further aggregated to the overall destination TSI using confirmatory factor analysis.

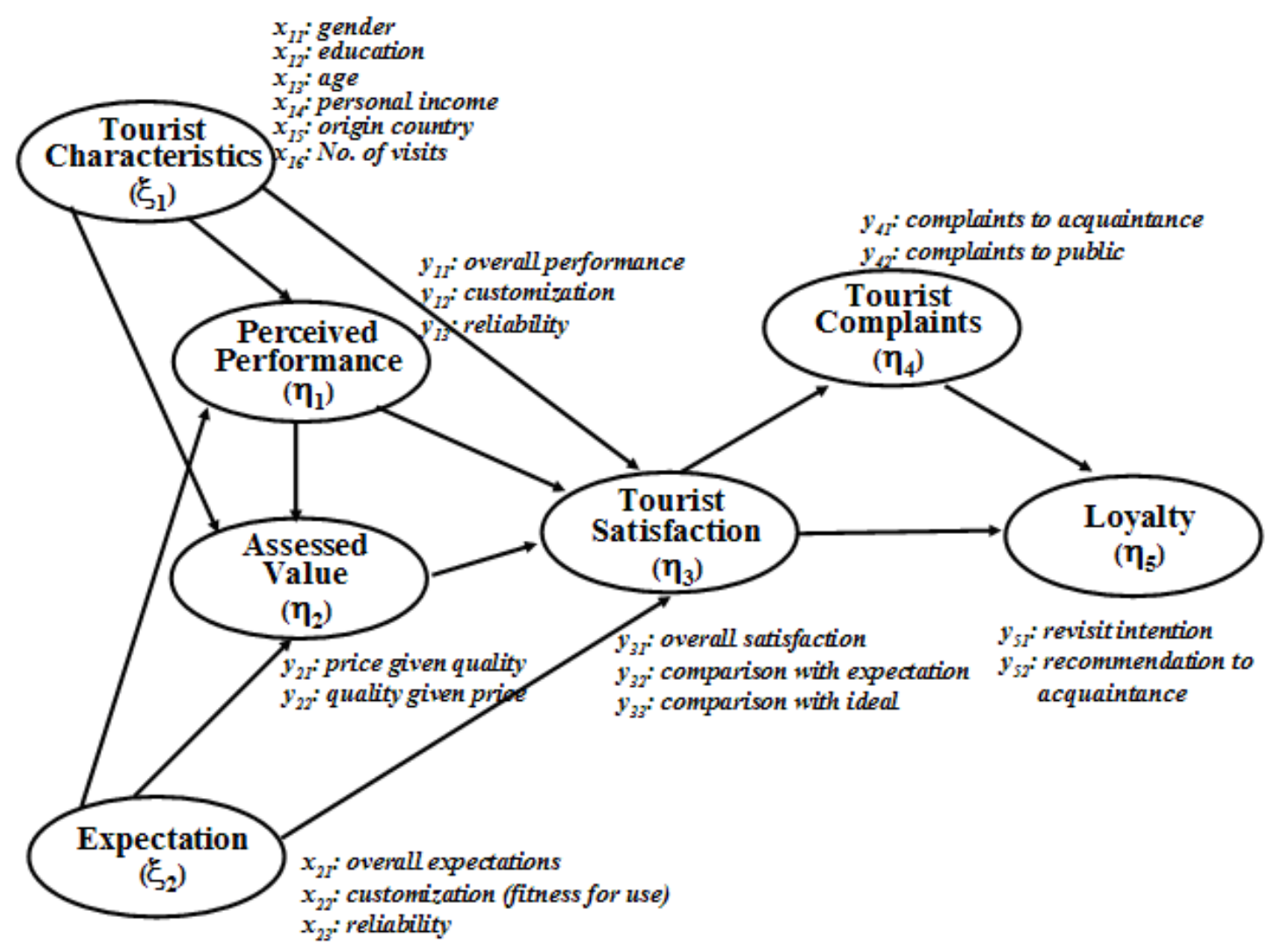

Figure 1. The Hong Kong Tourist Satisfaction Index (TSI) Model

The above developed Hong Kong TSI framework has been empirically tested firstly based on a pilot study on mainland Chinese tourists' satisfaction with three selected service sectors including hotels, retail shops and local tour operators in Hong Kong. The computed sectoral TSIs are 76.78, 73.01 and 72.82 out of 100 , respectively. The aggregated overall TSI is 74.04, with the retail sector satisfaction contributing the most to Chinese tourists' overall satisfaction, followed by the hotel sector satisfaction and then the local tour operator sector satisfaction (Song et al., 2011). It is noted that the tourist characteristics construct does not show significant influence on expectation, perceived performance or tourist satisfaction, and is therefore removed from the final sectoral TSI model. Similar results are reached in the subsequent main study (Song et al., 2012), which covers all major source markets and six key tourism sectors including attractions, hotels, immigration services, restaurants, retail shops and transportation. Based on the above Hong Kong TSI framework and the research instrument developed, the current study aims to further verify the theoretical model in a new and comparative setting. 


\section{Methodology}

This study adopts the general TSI framework developed by Song et al. (2011, 2012). Different from previous research design, this study applies the theoretical model of TSI in Figure 1 to the overall destination satisfaction assessment instead of the evaluation for each of the key tourism-related sectors. This research design is more suitable for a comparative study because the original design would double the length of the survey, and thus data collection would be extremely difficult. In the current study the sectoral level tourist satisfaction is also examined in order to establish the relationship with the overall satisfaction, but the antecedents and consequences of the sectoral level satisfaction are beyond the scope of this comparative study and are hence excluded from the survey. The research instrument is developed based on the studies of Song et al. $(2011,2012)$. The survey consists of four parts: overall destination satisfaction assessment of the UK, overall destination satisfaction assessment of Hong Kong, sectoral level satisfaction assessment of both the UK and Hong Kong, and demographics. In Parts One and Two, all constructs of the theoretical model in Figure 1 are included, measured by multiple items (see Figure 1). It should be noted that the tourist characteristics construct did not present any significant relationships with other constructs in the previous two studies; this study attempts to verify the finding by introducing the construct in the initial modelling process and examining the statistical significance of the relevant path coefficients. If none of the path coefficients is statistically significant, this construct will be dropped out from the model. The survey questions relating to their indicators use 11-point rating scales from 0 for "poor" to 10 for "excellent" to allow tourists to make better discriminations. There are 18 questions to measure the 5 constructs in relation to UK and Hong Kong overall satisfaction assessment, respectively. For Part Three, seven tourism-related service sectors are included and they are hotels, restaurants, retail shops, local tour operators, transport, visitor attractions and immigration services. These services are commonly experienced by most Chinese tourists in both Hong Kong and the UK. Satisfaction with each sector's service is measured by three items in line with the overall satisfaction measurement in Parts One and Two. Part Four includes six questions with regard to the respondent's gender, age, education, income and frequencies of visiting the UK and Hong Kong.

The target population of this survey is mainland Chinese tourists who have visited both Hong Kong and the UK over the past 12 months. A face-to-face street intercept survey using a self-administered questionnaire was employed. The convenience sampling method was adopted. The surveys were carried out at popular tourist spots in the UK such as city centres of Cambridge and Oxford, main attractions in London including Winsor Castle, the British Museum, Leicester Square and Oxford Street, as well as two major outlet shopping centres in Portsmouth and Bicester Village. Once a potential respondent was approached, a filter question was asked: "Did you visit Hong Kong over the past 12 months?" The survey continued only if a positive answer was given. During three weeks of data collection in April 2010, over 230 Chinese tourists were interviewed. Among all responses 161 were valid and contained less than $10 \%$ missing values, and were thus usable for this study. 


\section{Results and Analysis}

The sample of 161 valid responses are used for the following analysis including estimating two structural equation models (SEMs) for the overall satisfaction with the UK and Hong Kong respectively, based on the theoretical model in Figure 1, followed by another two SEMs which establish the relationships between sectoral satisfaction and overall satisfaction. Overall TSIs and sectoral TSIs are then computed based on the above SEMs. Finally, statistical differences between the two sets of TSIs in relation to Hong Kong and the UK are respectively tested.

\section{Demographic Profiles of the Sample}

The demographic profiles of the survey respondents are presented in Table 1. As it suggests, there is a good balance between male and female respondents; half of them are aged between 26 and 45; the majority (over 85\%) of the respondents received university level education or above; their average monthly household income is above 30,000 RMB; $40 \%$ of them came to the UK for the first time and $63.4 \%$ of them had visited Hong Kong for no more than three times. This is a gender balanced, mostly middle-aged, highly educated and relatively wealthy group of mainland Chinese travellers with limited travel experience abroad.

Table 1. Profile of Survey Respondents

\begin{tabular}{lrlr}
\hline Variable & \% & Variable & \% \\
\hline Sex & & Education & \\
Male & 52.2 & No formal education & .6 \\
Female & 47.8 & Primary/elementary school & .6 \\
& & Secondary/high school & 12.4 \\
& & College/university & 54.0 \\
& & Postgraduate & 32.3 \\
Age & & Monthly income (RMB) & \\
$16-25$ & 21.1 & $<7,000$ & 14.3 \\
$26-35$ & 28.0 & $7,000-20,999$ & 36.0 \\
$36-45$ & 24.2 & $21,000-34,999$ & 23.0 \\
$46-55$ & 18.6 & $35,000-48,999$ & 5.6 \\
$56-65$ & 3.7 & $49,000-69,999$ & 11.2 \\
$\geq 66$ & 4.3 & $\geq 70,000$ & 9.9 \\
& & & \\
Number of past visits to the UK & & Number of past visits to Hong Kong \\
0 & 41.0 & $1-3$ & 63.4 \\
$1-3$ & 40.4 & $4-6$ & 13.0 \\
$4-6$ & 6.2 & $7-9$ & 5.6 \\
$7-9$ & 1.2 & $\geq 10$ & 18.0 \\
$\geq 10$ & 11.2 & & \\
\hline
\end{tabular}

Note: All percentages are calculated on the basis of valid responses. 


\section{Destination Satisfaction Analysis}

The computing programme Smart-PLS 2.0 M3 was employed to run SEMs. Both the inner (structural) and outer (measurement) models were estimated using the partial least squares (PLS) method. Since tourist surveys are usually subject to some non-responses, missing data need to be imputed before estimating the model. The expectationmaximisation (EM) algorithm in SPSS 18 was employed to impute the missing values and obtain a complete data set. Model validity was assessed by determining the significance of the model's estimated path coefficients using the bootstrapping option, in line with Song et al. $(2011,2012)$.

\section{Model reduction}

The original theoretical model of tourist satisfaction in Figure 1 is estimated for Hong Kong and the UK, and the results (see Figures 2 and 3) show high consistency with the results of Song et al. (2011). None of the path coefficients between the tourist characteristics construct and its consequences is significant in both cases of the UK and Hong Kong. This result indicates that these characteristics have little influence on tourist satisfaction, perceived performance or assessed value. In line with Song et al. (2011, 2012), the tourist characteristics construct is removed from the model. In addition, the proposed paths from tourist satisfaction to tourist complaints and from tourist complaints to loyalty are not significant in both destination cases. The non-significant path from tourist complaints to loyalty is consistent with the findings of Song et al. (2011, 2012). These findings suggest that tourist complaints do not have a significant moderating effect on the relationship between tourist satisfaction and loyalty. These findings can be explained by the fact that Chinese tourists lack an intention to complain. As Ap (2000) noted, Chinese tourists as well as some other Asian tourists tend to keep silent instead of expressing dissatisfaction to "save face" and to avoid embarrassing vendors. The tourist complaints construct is therefore removed from the model. The remaining path coefficients are highly consistent with the hypothesised model and are in line with the results of Song et al. (2011) in terms of statistical significance. After removing the tourist characteristics and tourist complaints constructs, the reduced model is re-estimated and assessed in the next section. 


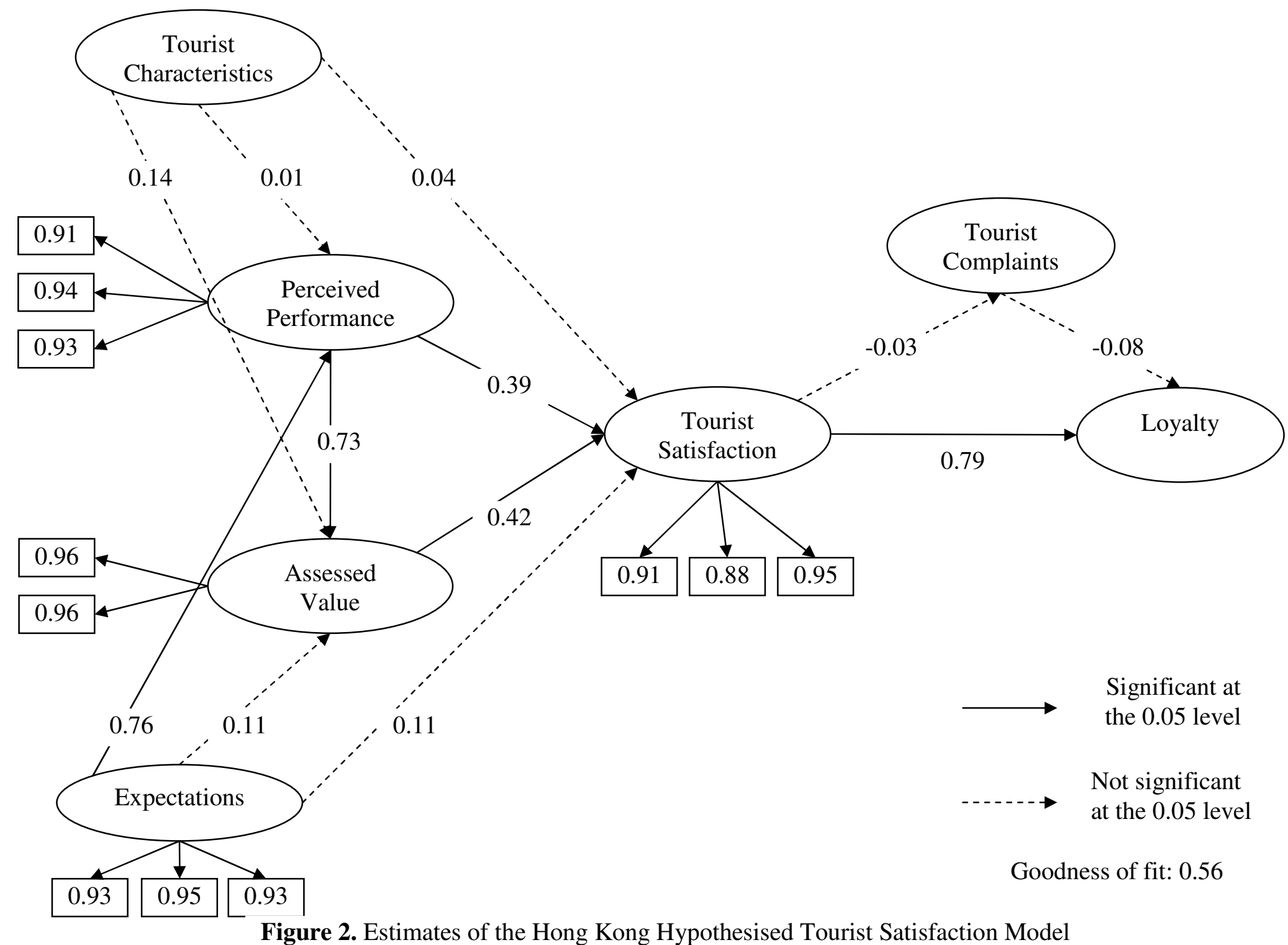




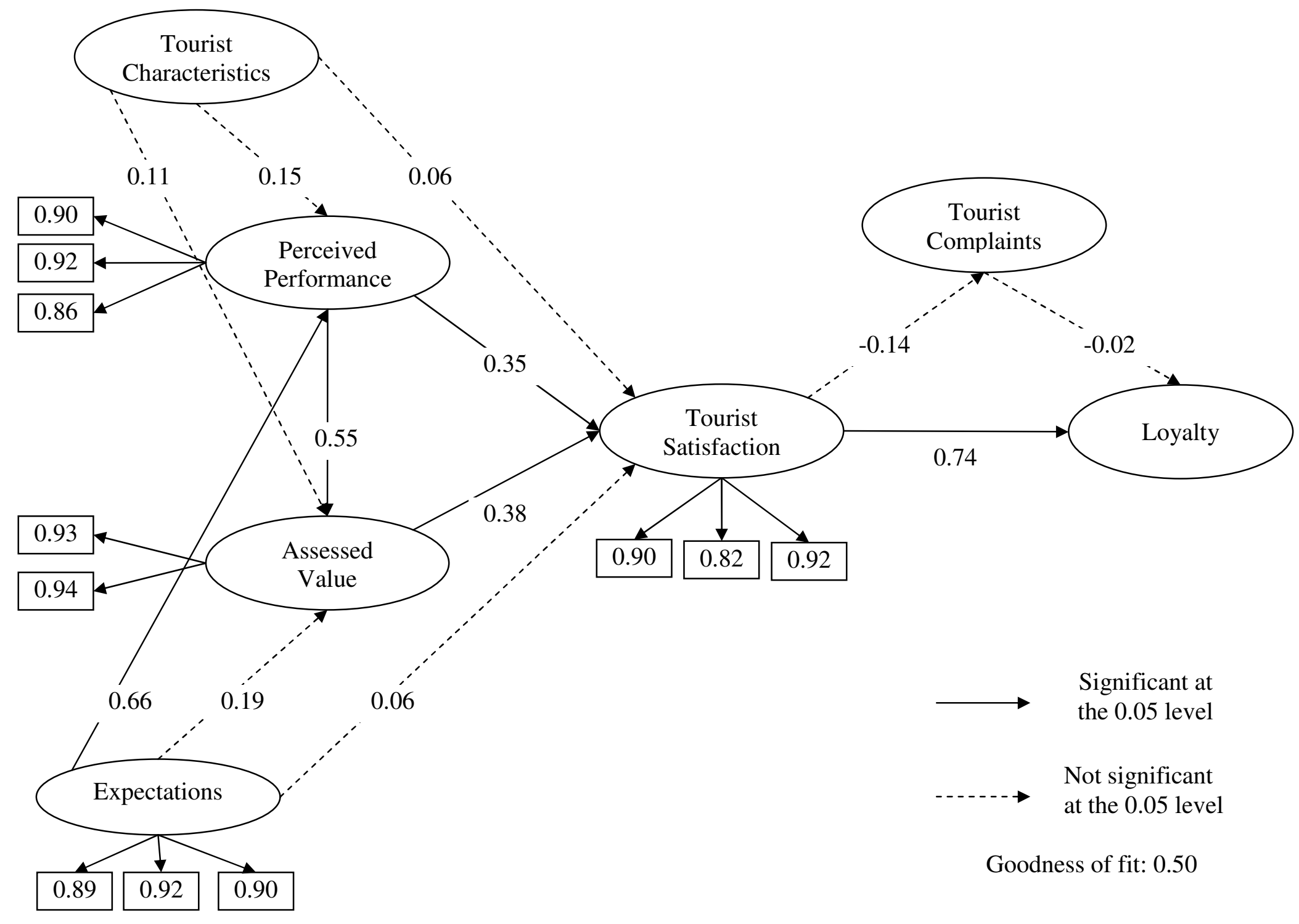

Figure 3. Estimates of the UK Hypothesised Tourist Satisfaction Model 


\section{Reliability and model fit}

The results of the final models are highly consistent with those of the original model regarding the values and significance levels of the remaining constructs (see Tables 2-4, Figures 4 and 5). As Figures 4 and 5 show, five out of seven paths are significant with a coefficient above 0.30. These results suggest that the final model has strong predictive power and removing the tourist characteristics and tourist complaints constructs does not affect the reduced model's validity and power. The reliability analysis was conducted to test the level of internal consistency for the measurements of all the reflective constructs. The indicators of the reflective constructs (tourist satisfaction, perceived performance, expectations, assessed value) are reliable because all standardised indicator loadings in both the UK and Hong Kong models are positive and significant. Moreover, convergent validity of each reflective construct is evidenced by the average variances extracted (AVEs) in Table 2. For both estimated models, the AVEs are consistently above 75 per cent, higher than the critical value of 50 per cent as recommended by Fornell (1992). This indicates that each reflective dimension and its respective indicators are highly correlated (Chan et al., 2003). In addition, a substantial degree of internal consistency is evidenced by the high Cronbach's alphas, which range from 0.86 to 0.93 (see Table 3 ).

Table 2. Average Variance Extracted of Estimated Models

\begin{tabular}{lcccc}
\hline Model & $\begin{array}{c}\text { Satisfaction } \\
(\%)\end{array}$ & $\begin{array}{c}\text { Performance } \\
(\%)\end{array}$ & $\begin{array}{c}\text { Expectations } \\
(\%)\end{array}$ & $\begin{array}{c}\text { Value } \\
(\%)\end{array}$ \\
\hline Hong Kong hypothesised model & 0.84 & 0.86 & 0.88 & 0.93 \\
Hong Kong final model & 0.85 & 0.86 & 0.88 & 0.93 \\
\hline UK hypothesised model & 77.5 & 79.8 & 81.3 & 88.0 \\
UK final model & 77.5 & 79.8 & 81.3 & 88.1 \\
\hline
\end{tabular}

Table 3. Cronbach's Alphas

\begin{tabular}{lcccc}
\hline Model & Satisfaction & Performance & Expectations & Value \\
\hline Hong Kong & 0.90 & 0.92 & 0.93 & 0.92 \\
The UK & 0.86 & 0.87 & 0.89 & 0.86 \\
\hline
\end{tabular}

Note: The results are the same for both the hypothesised and final models.

The $R^{2}$ s for the structural equations used to predict tourist satisfaction are reasonably high for all models (see Table 4). The structural equations for predicting perceived performance, assessed value and loyalty also present reasonable explanatory power. To assess the overall model fit, a global fit measure for PLS path modelling introduced by Tenenhaus, Vinzi, Chatelin, and Lauro (2005) is calculated for each of the estimated model. The results are shown in Figures 2-5. The goodness-of-fit values range from 0.50 to 0.77 , which all exceed the cut-off value of 0.36 for large effect sizes of $R^{2}$ (Wetzels, Odekerken-Schroder, \& van Oppen, 2009). This suggests that both hypothesised and reduced models perform well in both cases of Hong Kong and the UK. 


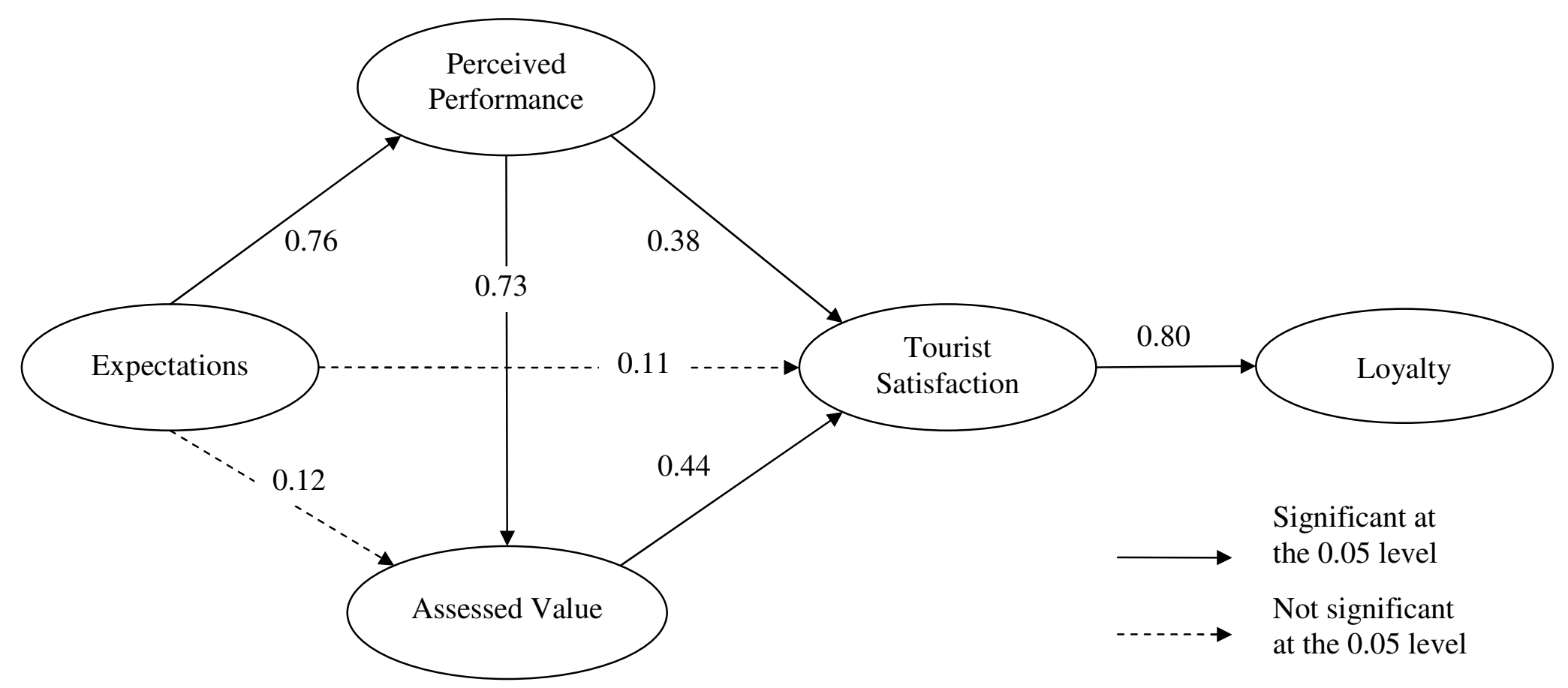

Goodness of fit: 0.77

Figure 4. Path Coefficients of the Final Hong Kong Tourist Satisfaction Model 


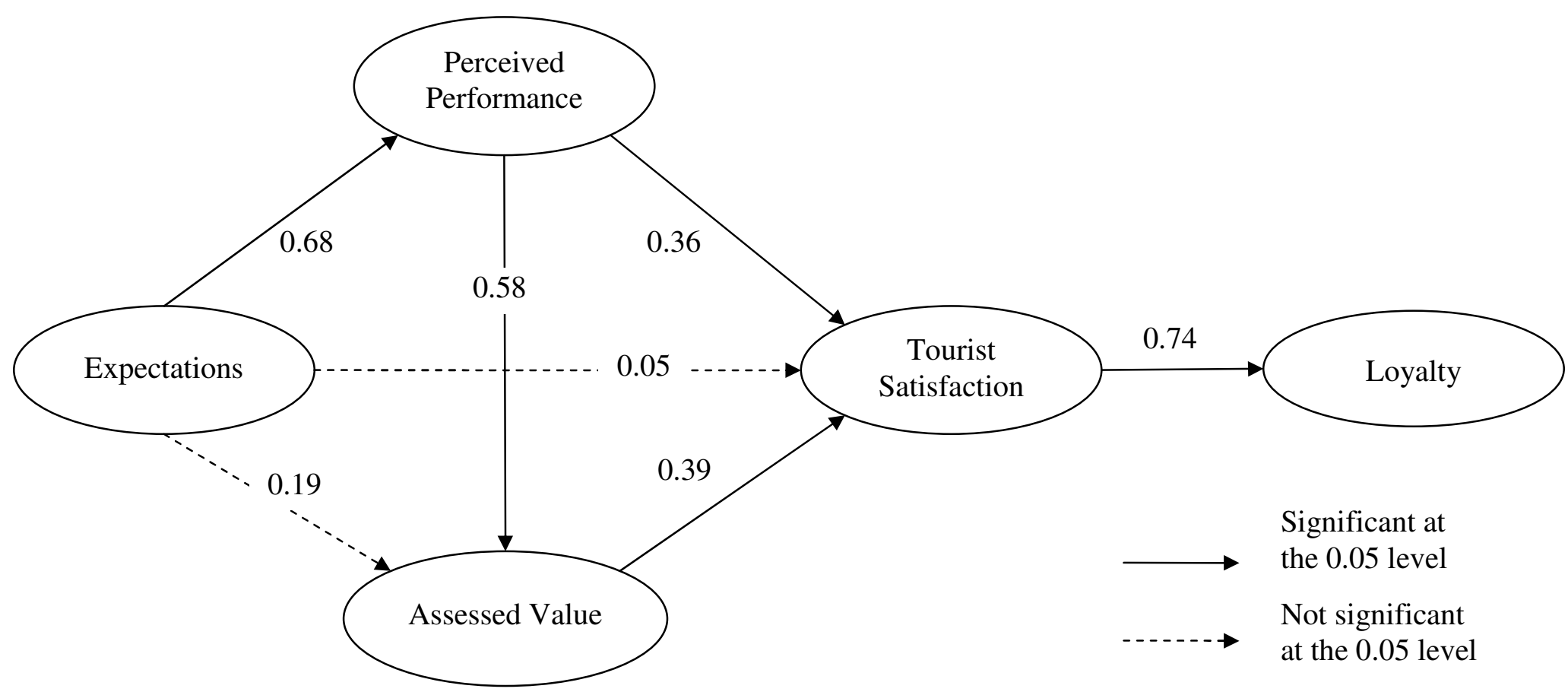

Goodness of fit: 0.65

Figure 5. Path Coefficients of the Final UK Tourist Satisfaction Model 
Table 4. Multiple $R$-squares $\left(R^{2}\right)$

\begin{tabular}{lccccc}
\hline Model & Satisfaction & Performance & Value & Loyalty & Average \\
\hline Hong Kong hypothesised model & 0.76 & 0.58 & 0.71 & 0.64 & 0.67 \\
Hong Kong final model & 0.76 & 0.58 & 0.69 & 0.63 & 0.67 \\
UK hypothesised model & 0.53 & 0.49 & 0.53 & 0.55 & 0.53 \\
UK final model & 0.53 & 0.47 & 0.52 & 0.55 & 0.52 \\
\hline
\end{tabular}

Comparisons between the estimation results of the original full model and of the reduced final model in both Hong Kong and the UK cases (see Tables 2-4) show that the reduced model has equal predictive power to the original one. Moreover, the reduced models show higher goodness-of-fit values than the hypothesised ones in both cases. It suggests that the more parsimonious model is a valid and effective option. High consistency between the UK and Hong Kong model estimates and between this study and that of Song et al. (2011, 2012) suggests the general applicability of the theoretical model of the Hong Kong TSI. The main difference between the final model of this study and that of the Hong Kong TSI is on the tourist complaints construct. The removal of this construct is based on the statistical insignificance of its both paths in the present study. This should be further verified in other empirical settings in the future.

\section{Structural relationships}

The significant paths in Figures 4 and 5 suggest that perceived performance plays a mediating role between expectations and tourist satisfaction and between expectations and assessed value. Tourists' initial expectations of various tourism services at a destination affect their evaluation of the received service performance, which in turn affects tourists' satisfaction level and their assessed value of the received services. In addition, perceived performance and assessed value both have positive and direct relationships with tourist satisfaction. The key role of perceived performance in tourists' satisfaction evaluation highlights the importance of improving service quality for destination competitiveness. Loyalty is a significant consequence of tourist satisfaction, and the estimated paths suggest a very strong correlation between tourist satisfaction and destination loyalty. Expectations show no significant relationship with either assessed value or tourist satisfaction. Similar findings are reported by other studies (e.g., Chan et al., 2003; Johnson, Anderson, \& Fornell, 1995).

\section{Computation of overall destination TSIs}

The overall destination TSI is computed using the model-implied weights (i.e., outer loadings of tourist satisfaction indicators in the estimated SEM). The TSI is then calculated as:

$$
\mathrm{TSI}=\frac{\omega_{\eta_{31}} \bar{y}_{31}+\omega_{\eta_{32}} \bar{y}_{32}+\omega_{\eta_{33}} \bar{y}_{33}}{\omega_{\eta_{31}}+\omega_{\eta_{32}}+\omega_{\eta_{33}}} \times 10
$$


where $\bar{y}_{31}, \bar{y}_{32}$ and $\bar{y}_{33}$ are the sample means of the three satisfaction indicators, and $\omega_{31}, \omega_{32}$ and $\omega_{33}$ are outer loadings of them. By multiplying a scaling constant 10 to the weighted average of the mean values of three satisfaction indicators the calculated TSI is expressed on a $0-100$ scale.

Based on the model estimates and the above formula, overall destination TSIs are computed for both Hong Kong and the UK, and they are 68.3 and 63.7, respectively. This result suggests that mainland Chinese tourists were more satisfied with their tourism service experience in Hong Kong than that in the UK.

\section{Computation of sectoral TSIs}

In order to further examine mainland tourists' satisfaction with individual tourism sectors in both Hong Kong and the UK, and their contributions to the overall destination satisfaction, another SEM is established (see Figure 6). In this model tourist satisfaction with each of the seven tourism-related sectors (i.e., hotels, restaurants, visitor attractions, retail shops, transport, local tour operators and immigration services) is included as an antecedent of overall destination satisfaction. The path coefficients represent the contribution of sector level satisfaction to overall destination satisfaction evaluation.

It should be noted that not all proposed path coefficients are expected to be significant, because not all encountered services at a destination affect a tourist's overall satisfaction significantly. The significant path coefficients are expected to have a positive sign given the positive correlation between sector level satisfaction and overall destination satisfaction. The outer loadings of each sector's satisfaction indicators are used to compute this sector's TSI based on Formula (1).

The estimation results are presented in Table 5 and Figures 7 and 8. Table 5 indicates that the estimated models are satisfactory. The indicators of all constructs are reliable as all standardised indicator loadings in both the Hong Kong and UK models are positive and significant. For both models estimated, the AVEs are consistently well above the critical value of 50 per cent. In addition, a substantial degree of internal consistency is evidenced by the high Cronbach's alphas, all above 0.80 .

Table 5. Estimation Results of Sector Level Satisfaction Models

Hotels Restaurants Shops Attractions Transport $\begin{gathered}\text { Tour } \\ \text { operators }\end{gathered}$ Immigration

\section{Hong Kong model}

$\begin{array}{cccccccc}\text { AVE } & 77.2 & 78.3 & 79.6 & 78.4 & 78.3 & 82.3 & 76.0 \\ \text { Alpha } & 0.85 & 0.86 & 0.87 & 0.86 & 0.86 & 0.89 & 0.84\end{array}$

Destination satisfaction $R^{2}=0.61$

\section{$\underline{U K \text { model }}$}

\begin{tabular}{cccccccc} 
AVE & 82.1 & 76.9 & 75.6 & 78.6 & 76.6 & 75.4 & 74.9 \\
Alpha & 0.89 & 0.85 & 0.84 & 0.86 & 0.85 & 0.84 & 0.83 \\
\multicolumn{7}{c}{ Destination satisfaction $R^{2}=0.49$} \\
\hline
\end{tabular}




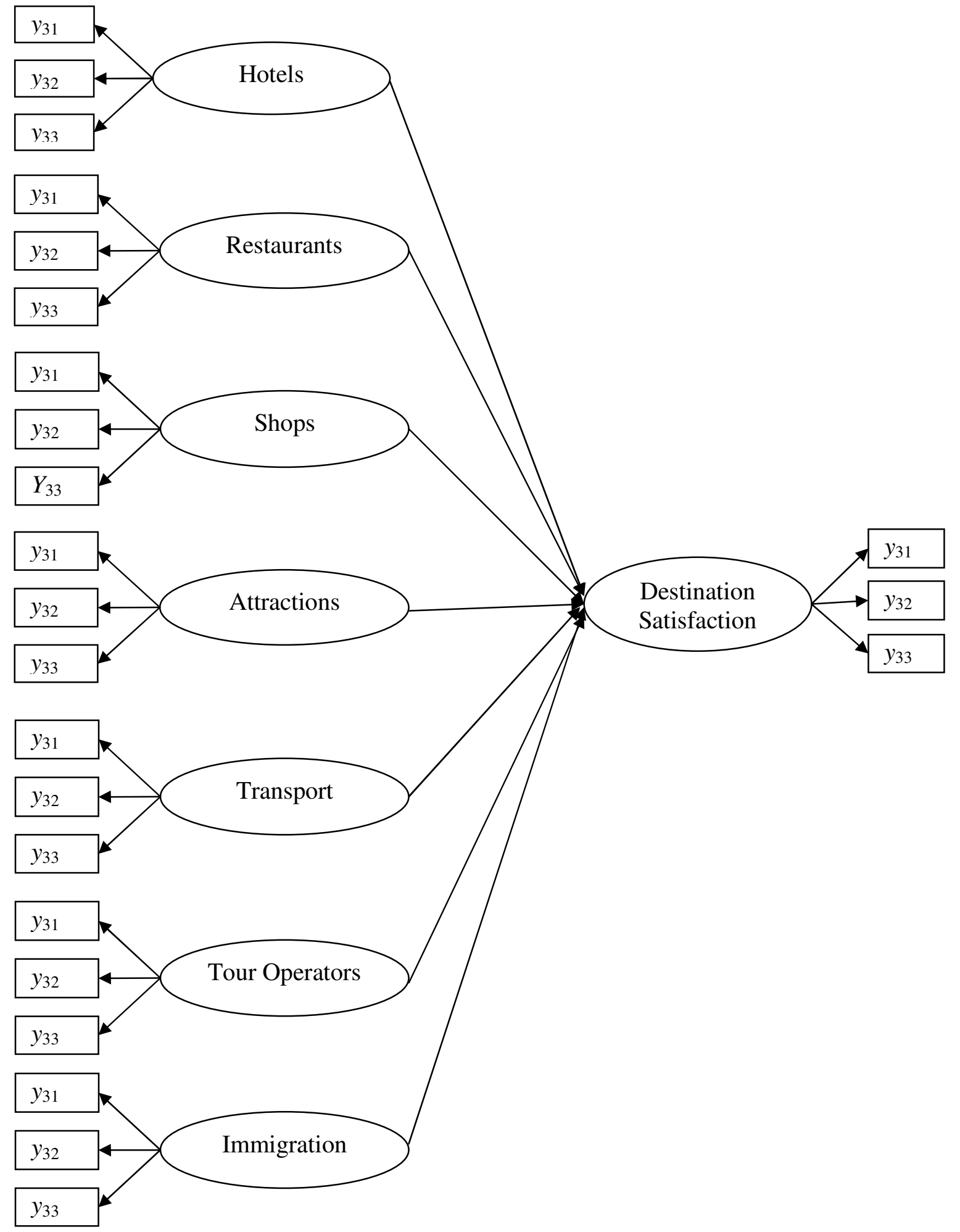

Figure 6. Sector-Level Satisfaction Model 


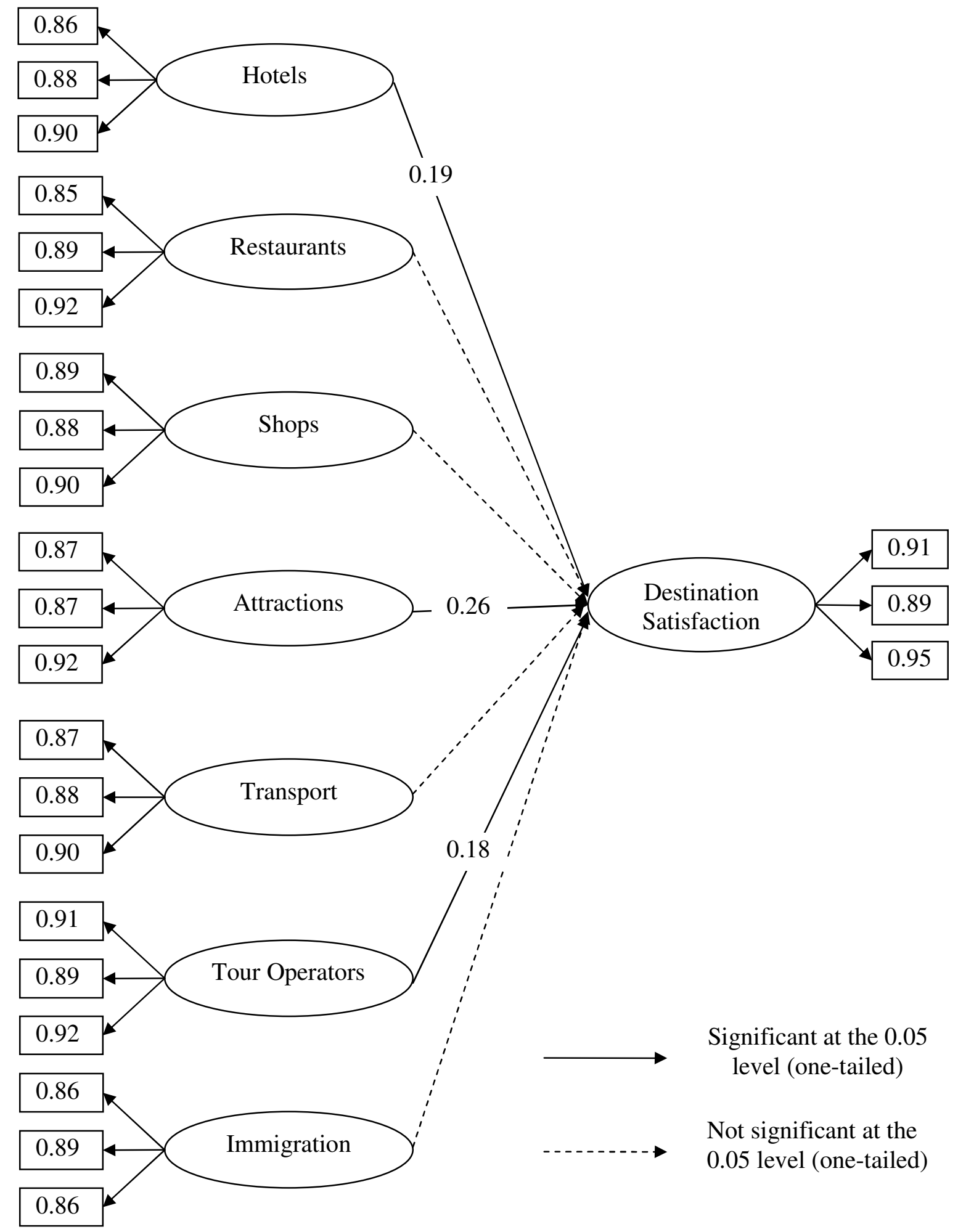

Figure 7. Estimated Hong Kong Sector-Level Satisfaction Model 


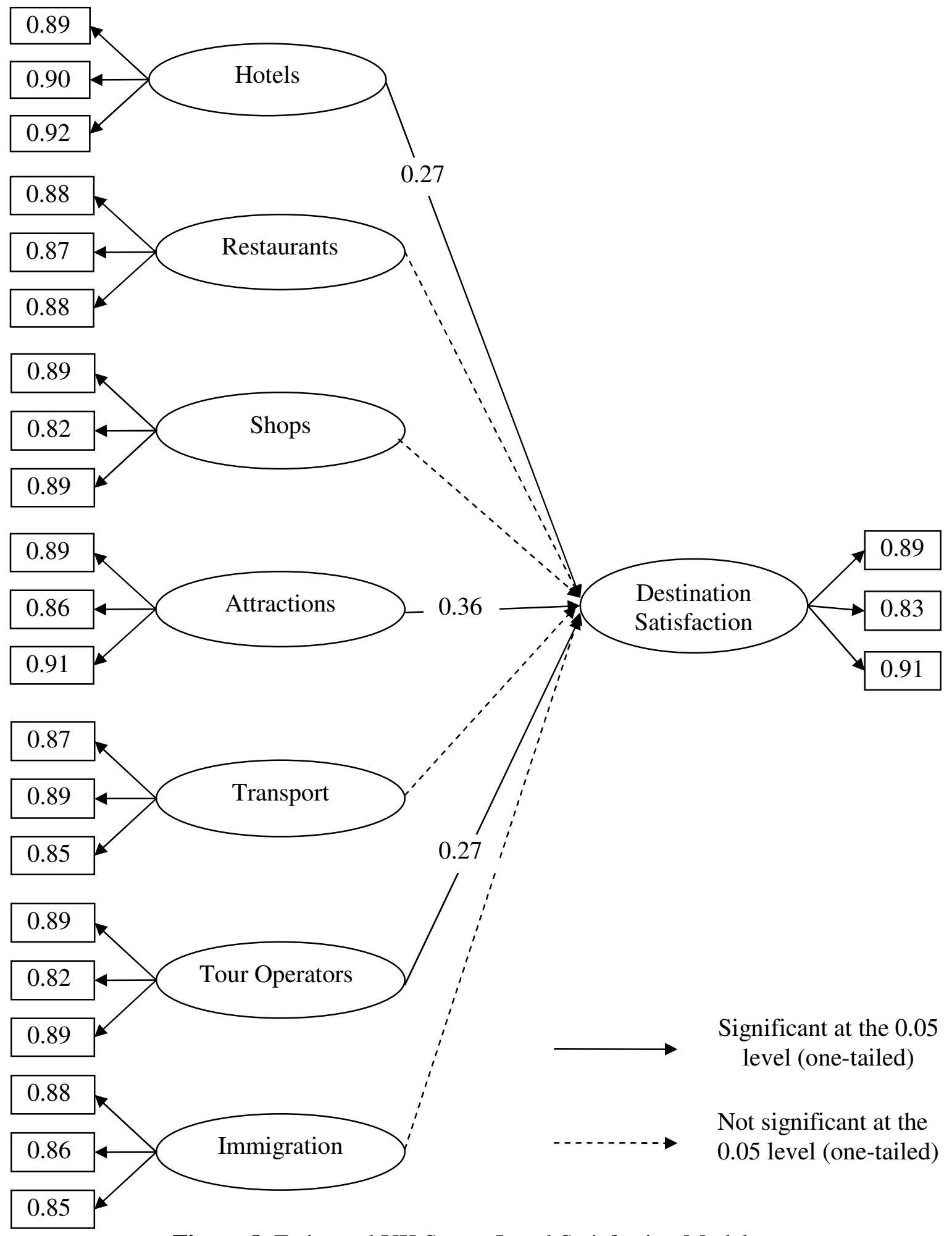

Figure 8. Estimated UK Sector-Level Satisfaction Model 
Figures 7 and 8 suggest that three tourism-related service sectors are significantly related to mainland Chinese tourists' overall satisfaction with both Hong Kong and the UK. They are visitor attractions, hotels and local tour operators. The relatively high contribution of visitor attractions' satisfaction to the overall satisfaction assessment can be explained by the fact that the primary purpose of most mainland Chinese visitors to Hong Kong and to the UK is for leisure and sightseeing. Therefore, to visit the wellknown visitor attractions accounted for a major part of their travel experiences in the UK and Hong Kong. This is particularly true for first-time visitors to a destination. Accommodation is one of the primary and necessary elements of travel and tourism, and therefore plays an important role in tourists' overall satisfaction. Due to language barriers and visa restrictions, most Chinese tourists joined guided tours when travelling overseas. Thus they had close contacts with tour guides throughout their trip. The service quality of the tour operator is therefore important for their overall satisfaction evaluation.

The computed sector-level TSIs of Hong Kong and the UK and their ranks are reported in Table 7. With respect to Hong Kong, mainland Chinese tourists were most satisfied with public transport services, followed by retail shops and immigration services, and least satisfied with local tour operators, followed by hotels. The efficient, costeffective and clean public transport system in Hong Kong is widely recognised by all international tourists. Shopping in Hong Kong is one of the key motivations of Chinese tourists. A good variety of international brands and reasonable prices, well-developed shopping facilities, together with language barrier-free service staff satisfied their shopping desires. The efficiency of immigration services and the staff's Mandarin language skills left a very positive first impression once they arrived in Hong Kong. On the other hand, the relatively low satisfaction score for local tour operators can be explained by the phenomenon of discounted tour packages. The highly discounted or even "zero-fee" tour packages result in a trade-off between low-quality accommodation and visits to high-priced souvenir and jewellery shops. This may also partially explain the relatively low satisfaction score of the hotel sector.

As far as the UK tourism sectors are concerned, mainland Chinese tourists were most satisfied with visitor attractions in the UK, followed by transport and retail shops, but least satisfied with hotels, followed by restaurant services. High satisfaction with attractions in the UK is confirmed by other studies regarding both culturally and geographically distant destinations of Chinese tourists (Li \& Carr, 2004; Ryan \& Mo, 2001). This can be explained by tourists' novelty-seeking motives. However, this finding does not mean that tourists would necessarily have low satisfaction with the attractions at a geographically or culturally close destination. Such a destination may also offer tourists some novel experiences, such as Hong Kong Disneyland for Chinese tourists. This may explain their high satisfaction with attractions in Hong Kong as well. Results of low satisfaction with hotels in both destinations are in line with past relevant literature (Leung, 2000; Wang et al., 2008). Language barriers seem to be a key issue particularly in those service encounters that require more human contacts and oral communication such as retail shops, restaurants and hotels. Some designer fashion stores in London and key shopping outlets in the UK have hired mandarin-speaking shop assistants, and therefore the language barriers have been mostly overcome. This contributes to Chinese tourists' relatively high satisfaction with the UK retail sector, compared to restaurant and hotel sectors where Chinese speaking employees are still rare. 
As discussed above, visitor attractions, hotels and tour operators are most relevant to mainland Chinese tourists' overall destination satisfaction assessment. The hotel sector is ranked low in both destinations. Visitor attractions in the UK seem to be particularly appealing for mainland Chinese tourists, which contribute the most to their overall satisfaction. On the other hand, attention should be paid to tour operator services in Hong Kong.

Table 6. Computed Sectoral and Overall TSIs for Hong Kong and the UK

\begin{tabular}{lcc}
\hline & Hong Kong & UK \\
\hline Visitor attractions & $66.2[5]$ & $66.3[1]$ \\
Hotels & $64.6[6]$ & $54.4[7]$ \\
Tour operators & $63.1[7]$ & $60.4[4]$ \\
Restaurants & $68.1[3=]$ & $56.3[6]$ \\
Retail shops & $68.3[2]$ & $62.2[3]$ \\
Transport & $70.3[1]$ & $65.1[2]$ \\
Immigration & $68.1[3=]$ & $58.0[5]$ \\
\hline Overall & 68.3 & 63.7 \\
\hline
\end{tabular}

Note: Figures in brackets refer to the ranks of sectoral TSIs in each destination case.

\section{Comparisons of TSIs between Hong Kong and the UK}

The above sections have presented the computed overall destination TSIs and sectoral TSIs for both Hong Kong and the UK. It seems that apart from the visitor attraction sector, mainland Chinese tourists were always more satisfied with tourism-related services in Hong Kong than those in the UK (see Table 6). In particular, mainland Chinese tourists' satisfaction scores with hotels, restaurants and immigration services are more than 10 points higher than those of the UK counterparts. These findings can be partially explained by travel motivation theories. Weiermair and Fuchs (2000) argued that tourist behaviour is driven by two contradictory motives: for novel experiences and for habitual experiences. Novelty seeking relates to new services, products, attractions or exotic destinations, while habitual tourism behaviour refers to the continuation of old habits, preferences and activities experienced in every-day life such as food preferences and eating habits. It can be argued that a tourist often has both motives during a single trip. He or she may pursue exotic cultural experiences at a new destination but maintain his/her eating habits. Regarding food and accommodation, most Chinese tourists may pursue habitual experiences during travel, and food and accommodation in Hong Kong are closer to their daily habit and therefore more satisfactory, compared to those in the UK. Novelty-seeking motives may apply to the experience with some exotic attractions, such as cultural/historical heritage and theme amusement parks. Since both the UK and Hong Kong offer some attractions to meet Chinese tourists' novelty-seeking needs, their satisfaction levels are almost equally high. However, when compared with other sectors at the same destination, Chinese tourists' satisfaction with visitor attractions is ranked much higher in the UK than in Hong Kong, top and fifth respectively. In this sense it can be argued that the UK does comparably better in offering Chinese tourists novel experiences. The following section further provides statistical evidence on the differences between these two sets of TSIs. 
Paired $t$-tests are employed to investigate whether mainland Chinese tourists' satisfaction with each tourism-related service sector and the destination as a whole is significantly different between Hong Kong and the UK. Although only three sectors' satisfaction levels are significantly related to the overall satisfaction evaluation, it is still useful to make comparisons across all of the seven sectors between the two destinations, given the managerial implications for each of the sectors under comparison. Table 7 presents the results of statistical tests. For the only sector where mainland Chinese tourists were more satisfied with in the UK than that in Hong Kong, i.e., visitor attractions, the satisfaction gap between the two destinations is not statistically significant. The same finding appears on the tour operator satisfaction comparison. For the other five sectors as well as the overall evaluation, Hong Kong receives significantly higher satisfaction scores than the UK. These findings suggest that Hong Kong has greater tourism competitiveness over the UK as far as the mainland Chinese tourist market is concerned.

Table 7. Statistical Tests of TSI Differences between Hong Kong and the UK

\begin{tabular}{lccc}
\hline & TSI $_{H K}$-TSI & $T$-statistic & $P$-value \\
\hline Visitor attractions & -0.1 & -.07 & 0.94 \\
Hotels & 10.2 & 6.30 & 0.00 \\
Tour operators & 2.7 & 1.66 & 0.10 \\
Restaurants & 11.8 & 7.33 & 0.00 \\
Retail shops & 6.1 & 4.58 & 0.00 \\
Transport & 5.2 & 3.54 & 0.00 \\
Immigration & 10.1 & 6.05 & 0.00 \\
Overall & 4.6 & 3.08 & 0.00 \\
\hline
\end{tabular}

\section{Concluding Remarks}

This study aims to compare mainland Chinese tourists' satisfaction with Hong Kong and the UK based on a newly developed TSI framework. The theoretical model of tourist satisfaction has been tested at the destination level. The empirical results are highly consistent with the previous studies of Song et al. $(2011,2012)$ based on the same model. The unique research design of such a comparative setting further suggests the wide applicability of the TSI theoretical model.

This study computes the overall destination TSIs and sectoral TSIs for both Hong Kong and the UK (see Figure 9 for a summary). On the whole, mainland Chinese tourists were more satisfied with Hong Kong than with the UK as their travel destinations. With respect to individual service sectors, mainland Chinese tourists were most satisfied with transport services and least satisfied with local tour operators in Hong Kong. Visitor attractions in the UK received the highest satisfaction score among the seven sectors and hotels received the lowest score. Among the seven sectors considered, visitor attractions, hotels and local tour operators show the most significant contributions to mainland Chinese tourists' overall destination satisfaction evaluation as far as both destinations are concerned. The comparison between the two destinations suggests that mainland Chinese 
tourists were more satisfied with six out of seven tourism-related service sectors in Hong Kong than in the UK. In particular, restaurants, immigration and hotels in Hong Kong all received over 10 points higher TSIs than their UK counterparts.

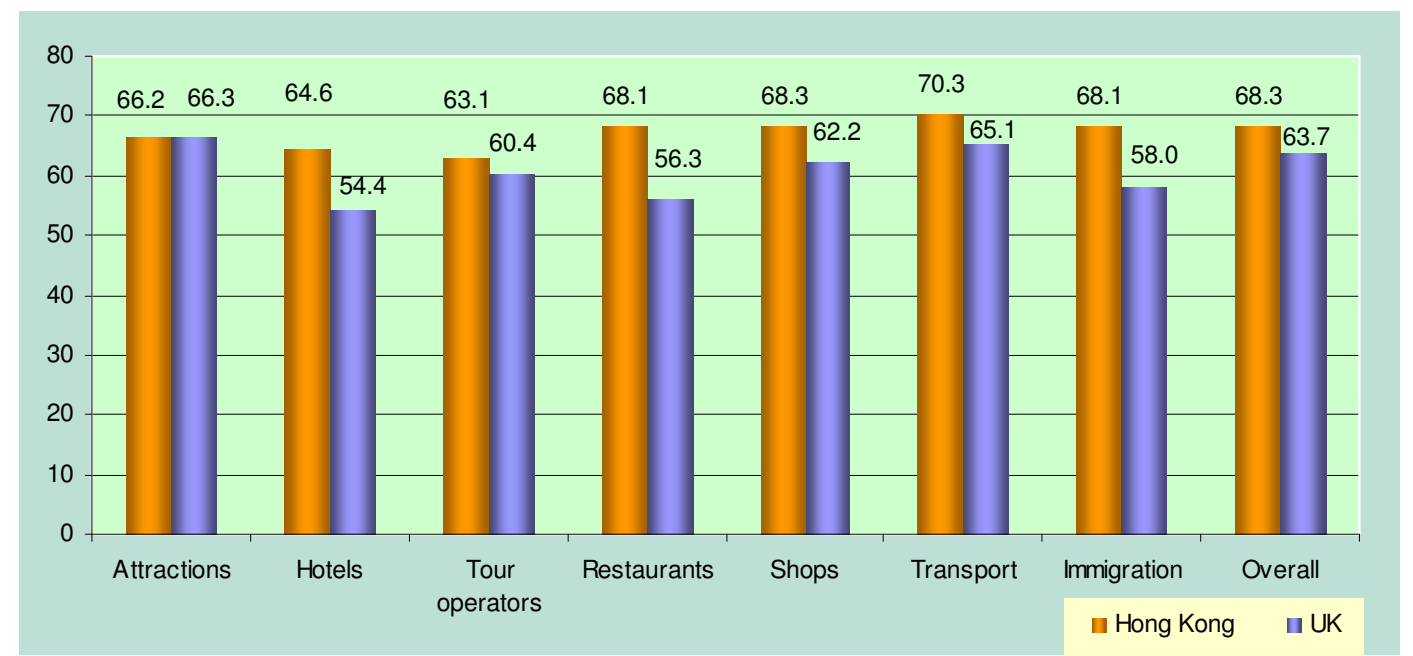

Figure 9. Hong Kong and UK TSIs Comparison

The above findings suggest that Hong Kong's tourism industry has gained more competitiveness over the UK as far as mainland Chinese tourists are concerned. This can be explained by the fact that many tourism and hospitality operators in Hong Kong have adopted industry-wide and/or internationally recognised service standards to ensure a high level of service, and particular effort has been put on understanding and satisfying this critical market, such as hiring mandarin-speaking service staff. In comparison, language barriers and cultural differences are more prominent in tourism sectors in the UK as a more culturally distant destination for Chinese tourists. Given the potential negative relationship between cultural distance and tourist satisfaction, tourism service providers in both Hong Kong and the UK should continue to improve their understanding of the cultural characteristics of the Chinese tourist market and adopt cross-cultural perspectives in their operations. Service providers need to be more aware of and sensitive to cultural differences. Relevant staff training including inter-cultural communication skills is necessary. Cultural knowledge will contribute to both service providers' business success and international tourists' satisfaction with their experience in inter-cultural encounters.

It should be noted that this study has a few limitations. First of all, the empirical study is based on a relatively small sample and the convenience sampling method, which may affect the generalisation of the findings. A larger scale of the study with a similar comparative setting should be considered. Secondly, the research design of this study has some differentiations from the studies of Song et al. $(2011,2012)$, although the theoretical model and methodology are highly consistent. Thus caution should be exercised when interpreting the results of this study in comparison to the others. As a comparative study, this paper focuses on the destination level satisfaction to test the theoretical model, while only the tourist satisfaction construct was measured in relation to each tourism sector in the survey. The different research designs and focuses lead to the computed TSIs at both destination and sector levels being not directly comparable with 
those of Song et al. (2011, 2012). Lastly, the survey was conducted in the UK, but the respondents also visited Hong Kong no more than 12 months before. Thus it can be argued that these respondents had clearer memories about their service encounters in the UK than those in Hong Kong. Since it would be extremely difficult to track the tourists and conduct the survey with them twice in both Hong Kong and the UK, this limitation is unavoidable for such a comparative study, although effort has been made to minimise the bias, such as omitting any response with over $10 \%$ missing values.

\section{Acknowledgement}

The authors would like to acknowledge the financial support of The Hong Kong Polytechnic University (Grant No.: 1-BB61).

\section{References}

Ap, J. (2000). Understanding the Asian respondent when conducting tourism research: some challenges, pitfalls and tips. In N. Nickerson, N. Mosey \& K. Andereck (eds), 31st Annual Conference Proceedings, Travel and Tourism Research Association (pp. 282-290). San Fernando Valley, CA: Travel and Tourism Research Association.

Boulding, W., Kalra, A., Staeling, R., \& Zeithaml, V. A. (1993). A dynamic process model of service quality: From expectations to behavioral intentions. Journal of Marketing Research, 30(2), 7-27.

Chan, L. K., Hui, Y. V., Lo, H. P., Tse, S. K., Tso, K. F., \& Wu, M. L. (2003). Consumer satisfaction index: New practice and findings. European Journal of Marketing, $37(5 / 6), 872-909$.

Chon, K. (2005). Opening address for the second China Tourism Forum and the third China Tourism Academy annual conference. Kunming, China, December 2005.

Fornell, C. (1992). A national customer satisfaction barometer: The Swedish experience. Journal of Marketing, 56(1), 6-21.

Fuchs, M., \& Weiermair, K. (2004). Destination benchmarking: An indicator-system's potential for exploring guest satisfaction. Journal of Travel Research, 42(3), 212225.

Grönroos, C. (1984). A service quality model and its marketing implications. European Journal of Marketing, 18(4), 36-44.

Henning-Thurau, T., \& Klee, A. (1997). The impact of customer satisfaction and relationship quality on customer retention: A critical reassessment and model development. Psychology and Marketing, 14(8), 737-764.

Heung, V. C. S. (2000). Satisfaction levels of mainland Chinese travellers with Hong Kong hotel services. International Journal of Contemporary Hospitality Management, 12(5), 308-315.

Hong Kong Tourism Board (2011). A statistical review of Hong Kong tourism 2010. Hong Kong: HKTB.

Johnson, M. D., Anderson, E. W., \& Fornell, C. (1995). Rational and adaptive performance expectations in a customer satisfaction framework. Journal of Consumer Research, 21(4), 28-40.

Kau, A. K., \& Lim, P. S. (2005). Clustering of Chinese tourists to Singapore: An analysis of their motivations, values and satisfaction. International Journal of Tourism Research, 7(4-5), 231-248. 
Kozak, M., \& Rimmington, M. (2000). Tourist satisfaction with Mallorca, Spain, as an off-season holiday destination. Journal of Travel Research, 38(3), 260-269.

Li, J. W. J., \& Carr, N. (2004). Visitor satisfaction: An analysis of mainland Chinese tourists on the Australian Gold Coast. International Journal of Hospitality and Tourism Administration, 5(3), 31-48.

Oh, H., \& Parks, S. C. (1997). Customer satisfaction and service quality: A critical review of the literature and research implications for the hospitality industry. Hospitality Research Journal, 20(3), 35-64.

Oliver, R. L. (1980). A cognitive model of the antecedents and consequences of satisfaction decisions. Journal of Marketing Research, 17(4), 460-469.

Parasuraman, A., Zeithaml, V. A., \& Berry, L. L. (1985). A concept model of service quality and its implications for future research. Journal of Marketing, 49(3), 41-50.

Qu, H., \& Li, L. (1997). The characteristics and satisfaction of mainland Chinese visitors to Hong Kong. Journal of Travel Research, 35(4), 31-41.

Ryan, C., \& Mo, X. (2001). Chinese visitors to New Zealand - Demographics and perceptions. Journal of Vacation Marketing, 8(1), 13-27.

Sirgy, M. J. (1984). A social cognition model of consumer satisfaction/dissatisfaction: An experiment. Psychology and Marketing, 1(2), 27-44.

Song, H., Li, G., van der Veen, R., \& Chen, J. L. (2011). Assessing mainland Chinese tourists' satisfaction with Hong Kong using the tourist satisfaction index. International Journal of Tourism Research, 13(1), 82-96.

Song, H., van der Veen, R., Li, G., \& Chen, J. L. (2012). Hong Kong tourist satisfaction index. Annals of Tourism Research, 39(1), 459-479.

Tenenhaus, M., Vinzi, V. E., Chatelin, Y. M., \& Lauro, C. (2005). PLS path modeling. Computational Statistics \& Data Analysis, 48(1), 159-205.

United Nations World Tourism Organization. (1999). World tourism organization tourism vision 2020. Madrid, Spain: Author.

United Nations World Tourism Organization. (2003). China outbound tourism. Madrid, Spain: Author.

VisitBritain. (2010a). Overseas visitors to Britain: Understanding trends, attitudes and characteristics. London, England: Author.

VisitBritain. (2010b). Written evidence from VisitBritain (TE 26). Retrieved February 14, 2012 , from

http://www.publications.parliament.uk/pa/cm201011/cmselect/cmtran/473/473we1 6.htm

VisitBritain. (2012). Market and trade profile: China. London, England: Author.

Wang, Y., \& Davidson, M. C. G. (2010). Pre- and post-trip perceptions: An insight into Chinese package holiday market to Australia. Journal of Vacation Marketing, 16(2), 111-123.

Wang, Y., Vela, M. R., \& Tyler, K. (2008). Cultural perspectives: Chinese perceptions of UK hotel service quality. International Journal of Culture, Tourism and Hospitality Research, 2(4), 312-329.

Weiermair, K., \& Fuchs, M. (2000). The impact of cultural distance on perceived service quality gaps. Journal of Quality Assurance in Hospitality and Tourism, 1(2), 59-75.

Wetzels, M., Odekerken-Schroder, G., \& van Oppen, C. (2009). Using PLS path modeling for assessing hierarchical construct models: Guidelines and empirical illustration. MIS Quarterly, 33(1), 177-195.

Wong, J., \& Law, R. (2003). Difference in shopping satisfaction levels: A study of tourists in Hong Kong. Tourism Management, 24(4), 401-410. 
Yi, Y. (1990). A critical review of consumer satisfaction. In V. A. Zeithaml (Ed.), Review of marketing (pp. 68-123). Birmingham, AL: American Marketing Association.

Yoon, Y., \& Uysal, M. (2005). An examination of the effects of motivation and satisfaction on destination loyalty: A structural model. Tourism Management, 26(1), 45-56.

Zhang, G., Song, R., \& Liu, D. (Eds.). (2011). Green book of China's tourism 2011: China's tourism development analysis and forecast. Heide, Germany: China Outbound Tourism Research Institute.

\section{Authors' biographies}

Gang $\mathrm{Li}$ is a Reader in Tourism Economics in the School of Hospitality and Tourism Management at the University of Surrey, Guildford, UK (E-mail: g.li@ surrey.ac.uk).

Haiyan Song is a Chair Professor of Tourism in the School of Hotel and Tourism Management at The Hong Kong Polytechnic University, Kowloon, Hong Kong, China (E-mail: hmsong@polyu.edu.hk).

Jason Li Chen is a Lecturer in Tourism and Events Management in the School of Hospitality and Tourism Management at the University of Surrey, Guildford, UK (E-mail: 1.chen@ surrey.ac.uk).

Doris Chenguang Wu is an Assistant Professor in the Sun Yat-sen Business School at Sun Yat-sen University, Guangzhou, China (E-mail: wuchenguang@ gmail.com) 